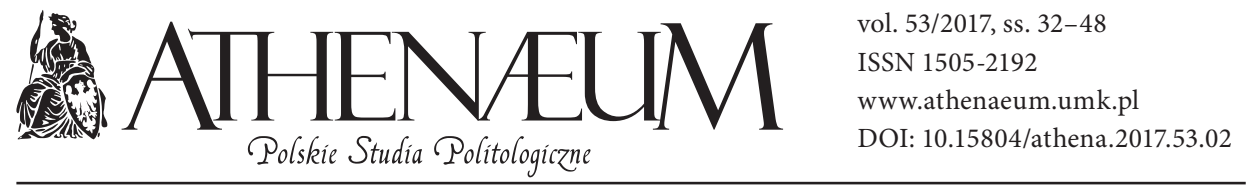

\title{
INTERWENCJA HUMANITARNA: MIĘDZY IDEA SUWERENNOŚCI PAŃSTW A UNIWERSALNYM WYMIAREM PRAW CZŁOWIEKA
}

\author{
HUMANITARIAN INTERVENTION: \\ BETWEEN THE IDEA OF STATE SOVEREIGNTY \\ AND THE UNIVERSAL DIMENSION OF HUMAN RIGHTS
}

Marta Turkot*

\begin{abstract}
- ABSTRAKT
Interwencja humanitarna jako działania podmiotów międzynarodowych wobec państw to akt, wobec którego idea suwerenności państw i wymogi powszechnie obowiązujących praw człowieka wchodzą w niejednoznaczne relacje. $\mathrm{W}$ artykule przedstawiono analizę idei suwerenności w kontekście interwencji humanitarnej i praw człowieka jako jej moralnego uzasadnienia. Okazuje się, że analiza tych relacji przynosi możliwość przedefiniowania pojęcia suwerenności i praw człowieka. Ukazane zostaje ponowne określenie ról tych idei, które mogą być przeprowadzone w oparciu o analizy tych związków.
\end{abstract}

Słowa kluczowe: interwencja humanitarna, suwerenność państwowa, prawa człowieka
Humanitarian intervention, as an action of international actors towards states, is an act under which the idea of state sovereignty and the requirements of a universally applicable human rights come into ambiguous relationships. The article presents the analysis of the idea of sovereignty in the context of humanitarian intervention and human rights as its moral reason. It turns out that the analysis of these relationships brings the opportunity to redefine the concepts of sovereignty and human rights. There is shown the re-identification of roles of these ideas, which can be made by analysis of these relationships.

Keywords: humanitarian intervention, state sovereignty, human rights

\footnotetext{
* Uniwersytet Warszawski, Instytut Filozofii.
} 
Interwencja humanitarna będąca działaniem podmiotów międzynarodowych wobec państw jest aktem, w ramach którego idea suwerenności państw oraz wymogi uniwersalnie stosowanych praw człowieka wchodzą w głębokie, często niejednoznaczne relacje. Cel, który sobie stawiam to, po pierwsze, próba rekonstrukcji dyskusji toczącej się wokół zagadnienia interwencji humanitarnej. Zaprezentowane zostaną argumenty zwolenników oraz przeciwników humanitarnego angażowania się w wewnętrzne sprawy drugiego państwa, zaznaczone zostaną także dylematy, które wynikają z obu postaw. Interwencja humanitarna istnieje w kontekście napięcia pomiędzy dążeniem do zachowania suwerenności państwa a wymogiem przestrzegania praw człowieka. Kolejnym celem artykułu jest przedstawienie propozycji zniwelowania tego napięcia poprzez próbę przeformułowania definicji suwerenności państw i wskazanie nowych aspektów uniwersalnego wymiaru praw człowieka. Oba pojęcia, dotychczas wchodzące w konflikt, ukazują się w nowym świetle.

Struktura artykułu została oparta najpierw na przedstawieniu przeciwstawnych podejść teoretycznych do zagadnienia interwencji humanitarnej. Podział owych stanowisk zostaje przeprowadzony w odniesieniu do wartości, takich jak suwerenność autorytetu państwa i praw człowieka, gdzie przeciwnicy interwencji humanitarnej cenią wyżej suwerenność, natomiast zwolennicy - prawa człowieka (owo przeciwieństwo wynika $\mathrm{z}$ istniejącego napięcia między absolutną władzą państwa a wolnością jednostek). Następnie zaproponowane zostaje przezwyciężenie tego podziału. Polega ono na przekonaniu, że jest możliwe zachowanie suwerenności państw przy jednoczesnym uznaniu uniwersalnego statusu praw człowieka, co ostatecznie stanowi opowiedzenie się za interwencją humanitarną, lecz poprzez redefinicję dotychczasowych reguł i kanonów postępowania w stosunkach międzynarodowych.

\section{WOKÓł DEFINICJI}

Interwencja to - powodowane różnymi motywami - angażowanie się jednego podmiotu systemu międzynarodowego w wewnętrzne sprawy oraz politykę prowadzoną przez inne państwo tego systemu (Mężykowska, 2008, s. 15). Zjawisko to budzi zróżnicowane oceny, jest kontrowersyjne ze względu na przyczyny i sposoby ingerowania, dlatego też brakuje jednej, powszechnie uznanej defini- 
cji ${ }^{1}$. Można wyróżnić trzy zasadnicze przyczyny i zarazem motywacje państw do podejmowania interwencji: 1) politykę imperialną - dążenie do powiększenia terytorium, interesy ekonomiczne, prawne, 2) obronę własnych obywateli oraz 3) „interes ludzkości” („interest of humanity”; Mężykowska, 2008, s. 16). Trzeci rodzaj intencji państw i podmiotów politycznych do angażowania się, w tym przede wszystkim w relacje między poddanymi i rządzącymi w danym państwie, można określić jako interwencję humanitarną.

Interwencja humanitarna to aktywność powzięta przez państwo lub innego aktora sceny politycznej, której celem jest ingerencja w wewnętrzne sprawy innego państwa z moralnych powodów, uwzględniających prawa człowieka (Spalding, 2013, s. 4). Różnica między interwencją a interwencją humanitarną polega na tym, że w pierwszym przypadku państwo lub podmiot polityczny decyduje się na zaangażowanie $w$ wewnętrzne sprawy innego państwa $z$ powodu ochrony własnego, bezpośredniego i indywidualnego interesu², natomiast w drugim przypadku działanie takie powinno charakteryzować się bezinteresownością oraz polityczną bezstronnością. Kontrowersyjność interwencji humanitarnej polega na tym, że kwestionuje ona dotychczasowe zasady porządku międzynarodowego, obowiązujące jeszcze od pokoju westfalskiego, mianowicie zasadę niezależności państw i ich suwerenności. „Z zasadą suwerenności nieodłącznie związany jest zakaz interwencji”, ponieważ stanowi ona bezpośrednie pogwałcenie prawa państwa do niezależności i samostanowienia (Mężykowska, 2008, s. 55). Co więcej, w Karcie Narodów Zjednoczonych wprost formułuje się zakaz interwencji: „Żadne z postanowień niniejszej Karty nie upoważnia Narodów Zjednoczonych do wtrącania się w sprawy, które zasadniczo należą do wewnętrznej kompetencji jakiego bądź państwa, ani do domagania się od członków, żeby sprawy tego rodzaju oddawali do załatwienia w trybie przewidzianym w niniejszej Karcie" (Karta Narodów Zjednoczonych art. 2 [7]). Innym znanym sformułowaniem zakazu ingerencji jest zawarty w Deklaracji passus zasad prawa międzynarodowego z 1970 roku: „Żadne państwo czy grupa państw nie ma prawa ingerować,

${ }^{1}$ Przedstawiciele „szkoły angielskiej” określają interwencję ogólnie jako aktywność powziętą przez państwo, grupę w ramach państwa, grupę państw lub międzynarodową organizację, która ingeruje przymusowo w wewnętrzne sprawy innego państwa (Vincent, 1974, s. 3). Z kolei przedstawiciele „szkoły walijskiej” uważają działania prewencyjne przed wybuchem konfliktu oraz inicjowane i realizowane przez zewnętrzne podmioty odbudowywanie pokoju i instytucji danego państwa tuż po konflikcie także za interwencje humanitarne (Bellamy, 2003, s. 331).

${ }^{2} \mathrm{~W}$ tym sensie interwencja jest uznawana za egzekwowanie prawa danego państwa, które jest łamane przez inne państwo (Rougier, 1910, s. 478). 
bezpośrednio lub pośrednio, z żadnych względów, w wewnętrzne lub zewnętrzne sprawy któregokolwiek państwa. W konsekwencji, interwencja zbrojna i wszelkie inne formy ingerencji lub próby zagrożenia podmiotowości państwa bądź jego politycznych, gospodarczych i kulturalnych elementów, stanowią pogwałcenie prawa międzynarodowego"3. Kontrowersyjność również w tym przypadku powoduje, że brakuje powszechnie akceptowanej definicji interwencji humanitarnej. Badacze ujmują ją albo jako instrument egzekwowania prawa międzynarodowego, albo przeciwnie, jako formę jego naruszania (Mężykowska, 2008, s.18). Dyskusje wywołuje także charakter humanitarnej interwencji - można wyróżnić bowiem ingerencję bez użycia siły (pomoc humanitarna) oraz przy użyciu siły (pomoc militarna).

Zasada suwerenności państw to reguła mająca swoją podstawę prawną w Karcie Narodów Zjednoczonych, można ją określić jako niezależność władzy państwowej od jakiejkolwiek innej władzy, zarówno w zakresie spraw wewnętrznych, jak i zewnętrznych (Karta Narodów Zjednoczonych, art. 2 [1]; Góralczyk, 1995, s. 116). Stanowi ona wypadkową różnych koncepcji władzy, poczynając od tych zakładających relację podległości rządzonych wobec rządzących państwem, po opierające suwerenność na utożsamieniu suwerena $\mathrm{z}$ ludem ${ }^{4}$. Łączy się z zasadami nieingerencji, równouprawnienia oraz samostanowienia narodów. Wszystkie te reguły zostały wyrażone w Deklaracji Zgromadzenia Ogólnego ONZ z 1970 r., gdzie można przeczytać m.in.: „Wszystkie państwa korzystają z suwerennej równości. Mają one prawa i obowiązki, i są równymi członkami społeczności międzynarodowej, bez względu na różnice gospodarcze, społeczne, polityczne i inne. (...) Żadne państwo nie może stosować ani zachęcać do stosowania ekonomicznych, politycznych lub jakichkolwiek innych środków przymusu wobec innego państwa, aby podporządkować go sobie w wykonywa-

${ }^{3}$ Deklaracja zasad prawa międzynarodowego dotyczących przyjaznych stosunków i współdziałania państw zgodnie z Kartą Narodów Zjednoczonych (zasada dotycząca obowiązku nieingerowania w sprawy należące do wewnętrznej kompetencji któregokolwiek państwa, zgodnie z Kartą NZ), Rezolucja Zgromadzenia Ogólnego ONZ, 1970. Podobne sformułowania można znaleźć w artykułach Protokołu Dodatkowego do Konwencji Genewskich: „Żadne postanowienie niniejszego protokołu nie może być powoływane dla usprawiedliwienia interwencji, bezpośredniej lub pośredniej, z jakichkolwiek powodów, w sprawy wewnętrzne lub zewnętrzne Wysokiej Umawiającej się Strony, na której terytorium toczy się konflikt”. Protokół Dodatkowy do Konwencji Genewskich z 12 sierpnia 1949 r. (dotyczący ochrony ofiar niemiędzynarodowych konfliktów zbrojnych) Dz.U. z 1992 r., Nr 41, poz. 175.

${ }^{4}$ W kwestii ewolucji znaczenia pojęcia suwerenności (Reisman, 1990, s. 866). 
niu jego suwerennych praw i uzyskać od niego jakiegokolwiek rodzaju korzyści” (Rezolucja Zgromadzenia Ogólnego ONZ, 1970).

Jakkolwiek suwerenność państw jest fundamentem stosunków międzynarodowych, co znajduje swój wyraz w prawie międzynarodowym, to w zderzeniu z coraz bardziej rozpowszechnionym podejściem do uwzględniania praw człowieka w stosunkach między państwami wydaje się, że dotychczasowy model niezależności państw jest niewystarczający lub niezupełnie przystający do współczesnych realiów świata polityki. Od lat 90. XX wieku, a ściślej od zakończenia zimnej wojny, w stosunkach między państwami zaszły zasadnicze zmiany - zaczęto odchodzić od koncepcji suwerenności zogniskowanej wokół państw na rzecz postaw uwzględniających prawa jednostek, demokratyzację rządzenia, a ostatecznie prawa człowieka i ich powszechny, ponadpaństwowy wymiar (Makinda, 2002, s. 119).

Uniwersalny charakter praw człowieka oznacza, że istnieją takie uprawnienia, które każdy posiada w równym stopniu, z racji swojego człowieczeństwa, czy inaczej ludzkiej godności (Vincent, 1986, s. 13). Nawet jeśli wszyscy zgadzamy się co do niezbywalnego charakteru praw człowieka jako moralnego atrybutu, którego państwo nie może naruszyć, to powstaje pytanie o zasięg stosowalności tych praw i uzasadnienia dla rozszerzania tego zakresu. Oznacza to mnogość interpretacji nie tylko praw człowieka, ale i postaw wobec interwencji humanitarnej (Forsythe, 2000). Autorzy zajmujący się kwestią interwencji humanitarnej uznają raczej uniwersalny status praw człowieka niż ten będący jedynie wyrazem przynależności do kultury Zachodu; tym samym uznają, że uprawnienia te są raczej identyfikowane niż konstruowane przez ludzi, a dopiero następnie kodyfikowane w oparciu o legalne systemy (Reisman, 1910; Vincent, 1986). Nie ulega wątpliwości, że obecnie prawa człowieka są elementem, który najbardziej wpływa na zmiany międzynarodowej jurysdykcji, w tym również rewizję znaczenia i zakresu stosowania zasady suwerenności i nieingerencji (Mężykowska, 2008, s. 59).

\section{ARGUMENTY PRZECIWKO INTERWENCJI HUMANITARNEJ}

Rozważając debatę toczącą się wokół problemu interwencji humanitarnej, należy zdać sobie sprawę, że jej przeciwnicy będą bronić zasady suwerenności państw, natomiast zwolennicy przeciwnie, uniwersalnego statusu praw człowieka, stojącego ich zdaniem ponad regułami nieingerencji i samostanowienia narodów. 
Historycznie rzecz ujmując, zasada suwerenności pojawiła się jako pierwsza, dużo wcześniejsza od pomysłu humanitarnej ingerencji jednego państwa w sprawy drugiego ${ }^{5}$. Dlatego refleksję należy rozpocząć od omówienia racji jej przeciwników.

W ramach realistycznych teorii relacji międzynarodowych uważa się, że osiągnięcie porządku w międzynarodowym społeczeństwie jest możliwe, jedynie wówczas gdy państwa zachowają suwerenność terytorialną (Czaputowicz, 2008, s. 57-103). Moralność jest raczej tym, co może ograniczać działalność państw w obronie własnych interesów na arenie międzynarodowej. Dlatego realistyczne koncepcje promują suwerenność państwa, stawiając ją ponad moralnością, a zatem popierają powstrzymywanie się od interwencji. Zwraca się uwagę, iż prawa człowieka nie są uniwersalne, bowiem nie ma większego autorytetu moralnego ponad państwo. W warunkach pluralizmu stanowisk w międzynarodowej społeczności, braku powszechnej zgody co do elementów konstytuujących prawa człowieka nie można podać uzasadnienia dla powszechnego uznania legalności interwencji (Devetak, 2007, s. 151-174). Odwołując się do słów Tomasa Hobbesa, twierdzi się, że nie istnieje żadna wspólna władza, która mogłaby utrzymywać wszystkie państwa społeczności międzynarodowej w pokoju, poza poczuciem strachu przed wybuchem wojny (Hobbes, 2009). Dlatego rozwiązaniem politycznym służącym pokojowi jest według realistów utrzymywanie równowagi sił (Czaputowicz, 2008, s. 38). Zatem jakakolwiek interwencja, również humanitarna, byłaby naruszeniem układu równowagi nie tylko wobec danego państwa, którego by dotyczyła, ale wobec całego systemu zrównoważonych wpływów.

W ujęciu tzw. „szkoły angielskiej”, uważanej za kontynuację myśli realistycznej ${ }^{6}$, państwo jest podmiotem autonomicznym pośród większej społeczności państw, które podzielają podobne wartości, zasady i instytucje, posiada ono swoją indywidualną tożsamość, której gwarantem jest suwerenność. Interwencja humanitarna jest niedopuszczalna, bowiem narusza ową suwerenność państwa, przez co zostaje zachwiany także system państw w ramach międzynarodowej

5 Zasada suwerenności państw została wprowadzona do nowoczesnej polityki międzynarodowej podczas pokoju westfalskiego w $1648 \mathrm{r}$. Temat całego porządku westfalskiego, opierającego się na zasadzie suwerenności państw narodowych, oraz jego przeobrażeń do dzisiejszego modelu kosmopolitycznego opisują w swojej książce Held i Stanford (1995). Natomiast idea interwencji humanitarnej powstała dzięki B. Kouchnerowi, pracownikowi nigeryjskiego Czerwonego Krzyża, założycielowi organizacji „Lekarze bez granic” w latach 70. XX wieku (Evans, 2008, s. 32-33, Dróżdż, 2014, s. 37).

${ }^{6} \mathrm{~W}$ artykule nie podnosi się dyskusyjnej kwestii kwalifikacji „szkoły angielskiej” do nurtu realistycznego. Dość wspomnieć, że bywa ona postrzegana także jako współczesna próba połączenia podejścia realistycznego i idealistycznego (Czaputowicz, 2008, s. 253). 
społeczności (Bellamy, 2003; Ayoob, 2002)ำ. Koncepcja powstrzymania się od ingerencji, dominująca w dyskursie „szkoły angielskiej”, opiera się na argumencie, że państwo jest jedynym źródłem suwerennego autorytetu (Gomes, 2010). Porządek międzynarodowy jest najlepiej utrzymany, kiedy państwa respektują autonomię i niezależność innych państw.

Ponadto, przedstawiciele „szkoły angielskiej”, jak na przykład Hans Morgenthau, podnoszą, iż w zasadzie państwa kierują się jedynie własnym interesem. W praktyce przedstawiają te interesy tak, aby wykazać zgodność z ogólnymi zasadami moralnymi, jednak jest to raczej źródłem zakłamania i grozi mesjanizmem, niż wyraża prawdziwe, wzniosłe pobudki ingerowania jednego państwa w sprawy innego (Morgenthau, 1978, s. 1-15). Pozytywne stanowisko zachodnich liberalnych demokracji dotyczące interwencji humanitarnych jest często krytykowane jako „brutalna eksternalizacja projektu liberalnej demokracji pod płaszczykiem interwencji humanitarnej” (Owens, 2005, s. 57) 8 .

Wspólnym mianownikiem podejść przeciwstawiających się interwencji humanitarnej jest stawianie moralności niżej w hierarchii wartości politycznych od wartości suwerenności państwa. Koncepcja państwa autonomicznego jest wyznacznikiem negatywnego podejścia do interwencji humanitarnej. Z kolei tym, co łączy stanowiska popierające taką interwencję, jest zgoda w kwestii ujmowania praw człowieka jako podstawy moralności, którą należy podzielać w społeczności międzynarodowej.

\section{ARGUMENTY NA RZECZ INTERWENCJI HUMANITARNEj ${ }^{9}$}

Zwolennicy interwencji humanitarnej wskazują na błędne - ich zdaniem - założenie poprzedników, które można streścić jako wartościowanie porządku ponad sprawiedliwość w systemie międzynarodowym (Ayoob, 2002, s. 84). Rozumieją oni sprawiedliwość jako wartość moralną, która nie może być egzekwowana,

7 Jednakże teoria solidarystyczna, uważana za nurt w ramach „szkoły angielskiej”, chociaż uznaje przekonanie o wadze suwerenności państwa w systemie międzynarodowym, traktuje interwencję humanitarną jako działanie legalne. W ramach teorii solidarystycznej popiera się społeczność międzynarodową, która egzekwuje prawo międzynarodowe w ekstremalnych przypadkach łamania moralnych standardów przestrzeganych przez wszystkich członków społeczności (Czaputowicz, 2008, s. 278-279; Butterfield, Wight, 1966, s. 227).

8 Oryginalnie: "the violent externalization of the project of liberal democracy under the label humanitarian intervention” (tłum. M.T.).

9 Argumenty te są formułowane w przeważającej mierze w ramach tzw. IR Theories. Są to teorie 
bowiem ogranicza te działania wymóg nieingerencji. Zdaniem zwolenników humanitarnej interwencji częstokroć zdarza się, że dla poszanowania suwerenności państw rezygnuje się z przyzwoitości, co ostatecznie prowadzi do, ocenianych jako niemoralne, zaniechań. Skupianie się na ochronie zasady suwerenności prowadzi do ignorowania realnej przemocy, pochodzącej z zewnątrz lub od samych rządzących, w imię bezpieczeństwa i raison detat (Devetak, 2010). Stanowiska, które popierają interwencję humanitarną, przyjmują odwrotne uzasadnienie stawiają sprawiedliwość i moralność ponad utrzymaniem porządku i równowagi sił systemu międzynarodowego ${ }^{10}$. Argumentacja na rzecz interwencji humanitarnej opiera się na kilku założeniach, najbardziej znaczące wydaje się to oparte na zestawieniu suwerenności i praw człowieka.

Zasadniczo, większość różnic między zwolennikami i przeciwnikami interwencji humanitarnej można porównać do ogólnych różnic między realistami i idealistami w zakresie teorii stosunków między państwami. I tak, dla idealistów podmiotami relacji międzynarodowych są jednostki ludzkie, zaś realiści widzą je w suwerennych państwach. Wynika $\mathrm{z}$ tego, że dla idealistów priorytetem będzie ochrona praw jednostek, natomiast w wersji realistycznej pierwszorzędne jest zachowanie interesów państwa, w tym przede wszystkim jego integralności wewnętrznej. Ponadto realiści interesują się zastanym światem, gdzie człowiek ma dostosowywać się do środowiska, które w tym przypadku oznacza międzynarodowy system kontrolowany przez najsilniejsze państwa. Z kolei idealiści widzą relacje międzynarodowe nie jako domenę konieczności, ale możliwości, gdzie środowisko państw może być kształtowane zgodnie z najważniejszymi potrzebami człowieka, stosując się do ogólnych standardów, takich jak prawa człowieka (Czaputowicz, 2008, s. 81) ${ }^{11}$. Według nich państwa nie kierują się

określane w nauce anglosaskiej jako „intervention rights theories”, czyli teorie naukowe traktujące o prawie do interwencji.

${ }^{10}$ Na przykład przedstawiciele liberalnego kosmopolityzmu za priorytet stawiają raczej łagodzenie ludzkiego cierpienia niż ochronę suwerenności państwowej (Bellamy, 2003, s. 338).

11 Uważa się, że podejście idealistyczne, a zatem również pozytywny stosunek do praw człowieka, jest postawą normatywną - wyznaczającą jak powinno być i nieuwzględniającą zastanych realiów rzeczywistości, natomiast realizm jest stanowiskiem opisującym zastaną rzeczywistość. Jakkolwiek idealizm jest teorią normatywną, bowiem postuluje budowanie porządku społecznego w oparciu o uniwersalne normy, to realizm nie jest wolny od założeń normatywnych. Takie mniemanie o realizmie choć powszechne, wydaje się błędne, bowiem realistyczne przesłanki o naturze człowieka, władzy, relacji między państwami również są normatywnymi roszczeniami wobec rzeczywistości, ich konkretną interpretacją. Wynikają z niej określone konkluzje co do tego, jak należy postępować w relacjach między państwami. Do takich przesłanek można zaliczyć choćby przekonanie o złej naturze człowieka, kierowaniem się przez państwa jedynie własnym interesem, dominację w stosun- 
przede wszystkim własnym interesem, ale dążą do harmonii celów i współpracy, uwzględniając postawy altruistyczne i bezinteresowne aktorów areny międzynarodowej. Takie postawy towarzyszyć powinny interwencji humanitarnej, a ponieważ państwa mogą kierować się takimi motywacjami, interwencja jest możliwa i w wielu przypadkach pożądana.

Następnie, dla idealistów prawa człowieka są znaczącą siłą i czynnikiem kształtującym politykę międzynarodową ${ }^{12}$. Pozwalają państwom na określenie swoich preferencji wobec innych państw, bowiem prawa człowieka stanowią wyznacznik, czy dane państwo jest demokratyczne, czy nie (Schmitz, Sikkink, 2002).

W końcu, gwarantem wszystkich pożądanych w stosunkach międzynarodowych wartości - bezpieczeństwa, pokoju, poszanowania godności człowieka jest wspólne odniesienie do respektowanej powszechnie sprawiedliwości, będącej wyrazem raczej moralnych dążeń wspólnoty narodów niż narzędziem ochrony własnych interesów państw. Jest to podejście przeciwstawne realistom, a także „szkole angielskiej”, której przedstawiciele twierdzą, że porozumienie co do wspólnych wartości nie jest możliwe w pluralistycznej społeczności międzynarodowej (Spalding, 2013, s. 7).

Następnie stanowisko, które można określić jako liberalny kosmopolityzm ${ }^{13}$, funduje swoje poparcie wobec interwencji humanitarnej na trzech założeniach. Po pierwsze, ludzie mają równe prawa i wolności, które muszą być chronione przez instytucje; ponadto wszyscy ludzie w równy sposób posiadają te prawa i wolności, niezależnie od kultury, religii, przynależności państwowej, narodowości itp.; w końcu, ochrona tych praw jest troską wszystkich jednostek, państw i organizacji państwowych i międzynarodowych. Pobudki dla interwencji huma-

kach między państwami sprzecznych interesów, siły, brak wiary w długotrwałą międzynarodową współpracę obliczoną na wspólny cel. Z drugiej strony takie opozycyjne ujmowanie idealizmu i realizmu może być uprawnione, jeśli zauważymy i przyjmiemy, że realizm jest teorią władzy, natomiast idealizm teorią sprawiedliwości.

12 W ramach idealizmu zakłada się także silniej, że ochrona i przestrzeganie uniwersalnych praw człowieka są najważniejszymi celami i wyznacznikami działań między narodami. Liam Spalding, jeden z badaczy zajmujących się tą kwestią, zwraca uwagę na humanitarny aspekt stosunków międzynarodowych. To, co „humanitarne”, konsekwentnie odnosi się do koncepcji praw człowieka (Spalding, 2013). Prace, w których definicje tego, co „humanitarne”, odnoszą się do idei praw człowieka i moralności, to na przykład: Ayoob, 2002, s. 81-102; Baer, 2011, s. 301-326; Bellamy, 2003, s. 321-340; Gomes, 2010, s.1-23, czy Roberts, 2000, s. 3-51.

13 Określenie to zapożyczam od L.A. Spaldinga. W literaturze pojawia się także określenie liberalizm kosmopolityczny (Beitz, 1994, s. 124). 
nitarnej pochodzą z moralnego obowiązku, jaki jest zakładany w myśl reguły: „jeśli ludzie są pozbawiani podstawowych praw człowieka i z tej przyczyny tracą możliwość dążenia do własnych projektów, wówczas inni mają pierwszorzędny obowiązek by im pomóc" (Teson, 2003, s. 97) ${ }^{14}$. Dalsze wsparcie dla działań humanitarnych $w$ innych państwach pochodzi z założenia, że różne wspólnoty wchodzące w skład społeczności międzynarodowej są w stanie i faktycznie osiągają porozumienie w kwestii najważniejszych standardów moralnych.

U podstaw uzasadniania interwencji humanitarnej leży prawo moralne, którym są prawa człowieka, a ściślej przekonanie o ich uniwersalizmie i globalnym zasięgu. Badacze znajdują owo usprawiedliwienie moralne już w klasycznych koncepcjach głoszących ideę suwerenności państw. Pierwszą z nich jest, paradoksalnie, myśl Tomasza Hobbesa, na którego powoływali się również przeciwnicy interwencji humanitarnej. Według Spaldinga filozofia Hobbesa ukazuje, że skoro człowiek jest naturalnie równy wobec innych ludzi, zarówno fizycznie, jak i mentalnie, wobec czego najsłabszy jest w stanie pokonać najsilniejszego, to naturalnie posiada równe prawa (Hobbes, 2009). Skoro wszyscy posiadają je w sposób równy, są one uniwersalne. Interwencja humanitarna jest zatem sprawiedliwa jako supremacja moralnej obrony tych praw ponad ideą suwerenności państwa (Spalding, 2013).

Perspektywy argumentujące na rzecz humanitarnych działań jednych państw wobec drugich poszukują usprawiedliwienia, odwołując się również do filozofii Immanuela Kanta. Filozof ujmuje moralność jako dostarczającą norm przewyższających autorytet suwerennego państwa (Kant, 2007). W tym ujęciu stosowanie przymusu, którym byłaby interwencja humanitarna, jest usprawiedliwione moralnie, a nawet sprawiedliwe jako usunięcie „przeszkody w procesie utrudniania osiągania wolności” i jednocześnie zgodne z uniwersalnymi prawami (Gomes, 2010). Liberalny kosmopolityzm bazuje na takim imperatywie moralnym do interweniowania przeciwko naruszeniom praw człowieka. Stanowisko to jest oparte na poszukiwaniu sprawiedliwości ponad, a czasem nawet i kosztem porządku w społeczności międzynarodowej. Aplikacja tej perspektywy do międzynarodowych praktyk dostarcza legitymacji dla interwencji humanitarnej jako moralnego prawa jednostek, grup, państw i podmiotów międzynarodowych.

14 Oryginalny tekst brzmi: „If human beings are denied basic human rights and are, for that reason, deprived of their capacity to pursue their autonomous projects, then others have a prima facie duty to help them" (tłum. M.T.). 
Obok stanowisk zakładających istnienie prawa do interwencji humanitarnej formułowane są także teorie sugerujące obowiązek takiego ingerowania (Baer, 2011; Devetak, 2007; Gomes, 2010). Również te podejścia z powodzeniem odwołują się do filozofii Kanta. W jej ramach naszym moralnym obowiązkiem jest asystować innym, gdy wymagają pomocy. Bez tej asysty jednostka popada w apatię i bierność wobec prawa, nawet w sytuacji krytycznej (Kant, 2007). Wobec tego interwencja okazuje się, zdaniem przedstawicieli omawianych teorii, moralnym obowiązkiem pozostałych członków międzynarodowej społeczności. Jednakże, w myśl teorii - powinny istnieć ograniczenia co do ponoszonych przez obywateli państw kosztów takiej pomocy. Mianowicie, jeśli jedni obywatele decydują się ponosić koszty, by chronić wolności innych, lepiej byłoby, gdyby robili to motywowani poczuciem właśnie moralnego obowiązku, a nie ponosili „ostateczną ofiarę," aby ochronić pozostałych (Bear, 2011). Z powyższych powodów zapewne łatwiej jest przyjąć, że potrzeba interwencji humanitarnej powinna posiadać status prawa, a nie obowiązku.

\section{SUWERENNOŚĆ PAŃSTW W POWIAZZANIU Z PRAWAMI CZŁOWIEKA}

Czy możliwe jest jednoczesne utrzymywanie zasady suwerenności państw wraz z towarzyszącymi jej regułami samostanowienia, nieingerencji i autonomii oraz wymogu przestrzegania praw człowieka, w tym ich ewentualnego egzekwowania poprzez interwencję? Idea suwerenności państw nie dopuszcza przecież kwestionowania ich wewnętrznej integralności poprzez humanitarne ingerencje.

Jednak wydaje się, że jest możliwe, by suwerenność państw mogła być utrzymywana wraz z międzynarodowym rozpoznaniem uniwersalnych praw człowieka i ich egzekwowaniem przez jedne państwa wobec drugich. Propozycję taką - powstałą z połączenia obu idei, wykluczających się, jak widzieliśmy poprzednio, aczkolwiek być może jedynie pozornie - można rozumieć jako „suwerenność jako odpowiedzialność" (Ayoob, 2002, s. 84).

W ramach tego pomysłu uważa się, że jeśli państwo nie potrafi zapewnić swoim obywatelom minimalnego stopnia bezpieczeństwa, wówczas suwerenność przestaje istnieć i humanitarne angażowanie się zostaje uzasadnione jako przywrócenie państwu jego suwerenności. Wraz z łamaniem praw człowieka państwo nie wypełnia swojego obowiązku ochrony życia obywateli (Ayoob, 2002, s. 82). Przekonanie to czerpie ponownie z myśli Hobbesa. Otóż można tę sytuację 
porównać $\mathrm{z}$ brakiem wypełnienia kontraktu społecznego przez państwo, które ma chronić życie swoich obywateli (Hobbes, 2007, s. 89). Wówczas ingerencja wynikająca $z$ humanitarnych pobudek jest jak najbardziej wskazana i uzasadniona moralnie. „Interwencję humanitarną można bowiem postrzegać jako zamach na suwerenność i niezależność państwa albo też jako działanie zmierzające do wyegzekwowania odpowiedzialności państw, które nie uznają (nie przestrzegają) swoich obowiązków międzynarodowych" (Mężykowska, 2008, s. 17).

Zgoda na przestrzeganie zasady suwerenności państw przy jednoczesnym uznaniu i egzekwowaniu praw człowieka poprzez możliwość interwencji jest zatem możliwa, gdy zdefiniuje się suwerenność warunkowo. Nie ma być ona postrzegana, jak dotychczas, jako wartość absolutna, ale raczej jako jeden $z$ atrybutów państwa, który może ono utracić (Ayoob, 2002, s. 84). Suwerenność państwa jest zatem zachowywana i respektowana na arenie międzynarodowej, jeśli państwo spełnia określone warunki wobec swoich obywateli. Są nimi określone w kontrakcie społecznym zapewnianie bezpieczeństwa obywateli, zobowiązanie się do poszanowania ich praw i wolności. Gdy nie zostają one spełnione lub zaczynają być łamane, wówczas wygasa roszczenie państwa do suwerenności. W obliczu takiej sytuacji humanitarne wtargnięcie nie narusza samej suwerenności państw. Natomiast niespełnianie warunku znosi lub zawiesza atrybut samostanowienia państwa. Suwerenność jest w takim ujęciu ściśle łączona z odpowiedzialnością państwa za swoich obywateli (Mężykowska, 2008, s. 55$)^{15}$.

Przy takim ponownym określaniu suwerenności pojawia się także termin „suwerenność ludu”16. Jest on wyrazem próby przesunięcia podmiotu suwerenności z władzy na obywateli. Jeżeli władza nie jest w stanie chronić swoich poddanych, wówczas traci atrybut samostanowienia i inne państwa lub organizacje międzynarodowe mają prawo wkroczyć w celu obrony praw obywateli (Mężykowska, 2008, s. 55).

15 Redefinicje idei suwerenności państw w oparciu o uwzględnianie wagi praw człowieka proponują także badacze tacy jak David Held, Robert Fine czy Holli Thomas (Held, 1995; Fine, 2009; Thomas, 2004, s. 5).

16 Idea „suwerenności ludu” została po raz pierwszy wyrażona przez Johna Locke’a, jak zauważa Holli Thomas (Thomas, 2004, s. 13). Rząd gwarantuje ochronę praw jednostkowych, natomiast tylko jednostkowa zgoda może legitymizować rząd. Suwerenność państwa leży zatem w rękach ludzi, jego obywateli. Niezdolność do ochrony tych praw znosi prawo do legalnej władzy i suwerenności. Jednak, jak zauważa autorka, suwerenność ludowa była w nowoczesnym państwie podporządkowana suwerenności państwowej (Thomas, 2004, s. 13). O „suwerenności ludu” pisze także profesor Yale University Seyla Benhabib (Benhabib, 2007, s. 19-36; Turkot, 2016). 
Powyższa redefinicja suwerenności spotyka się także z krytyką. Jej przedstawiciele podkreślają, że prawom człowieka próbuje się przypisać, podobnie jak suwerenności, absolutne znaczenie. Prawa człowieka są traktowane jako ostateczny autorytet, na mocy którego można usprawiedliwiać różne, niekoniecznie bezinteresowne, ingerencje. Samo roszczenie do statusu ostatecznej instancji jest dla krytyków nieuzasadnioną uzurpacją, wśród wielości i jednoczesnej równości porządków wartości. Moralny wymiar praw człowieka jest uważany przez krytyków za kolejny, jeden z wielu konstruktów politycznych, podobnie jak inne wadliwych ${ }^{17}$.

Mimo znajomości argumentów krytycznych wielu badaczy decyduje się na przyjęcie tak zredefiniowanej kategorii suwerenności państw (Spalding, 2013, s. 11). Warunek owej niezależności państw wyznaczają bowiem nie tylko same prawa człowieka - niezależnie od tego, jaki zakres lub status zostanie im wyznaczony - ale także kontrakt społeczny, który w państwach demokratycznych ma wiele wyrazów ustawowych, instytucjonalnych, a także bywa czasowo renegocjowany.

W kontekście idei „suwerenności jako odpowiedzialności” warto wspomnieć o pomyśle obowiązku ochrony ludności dotkniętej kryzysami, tzn. „responsibility to protect” („RtoP” czy też „R2P”). Jest to koncepcja zaproponowana przez Kofi Annana, podobna do postulatów interwencji humanitarnej, choć wykraczająca poza nie, proponując szerszy zakres międzynarodowej pomocy (Dróżdż, 2014, s. 55). Pośród szczegółowych niuansów obu propozycji koncepcja R2P skupia się przede wszystkim na zapobieganiu eskalacji konfliktów, przy czym nie toleruje używania siły, skupia się jedynie na perspektywie ofiar, a nie podmiotów interweniujących, oraz każdorazowo wymaga akceptacji dla swoich działać od Rady Bezpieczeństwa ONZ. Wspólną wartością podzielaną przez zwolenników R2P i interwencji humanitarnej jest podważanie suwerenności państw jako absolutnej wytycznej w działaniach międzynarodowych oraz popieranie redefinicji dotychczasowej idei suwerenności, tak by uwzględniała prawa jednostek (Evans, 2008).

Przy określonej na nowo idei suwerenności swoistej redefinicji ulega również znaczenie praw człowieka. Wydają się one teraz warunkami, które mogą wyznaczać suwerenność państwa. Innymi słowy, stanowią one powody, ze względu

17 Krytyka zredefiniowanego pojęcia suwerenności państw, będącego kluczowym zabiegiem w ramach podejścia popierającego interwencję humanitarną, na przykład przez J. Mosesa (idem, 2006). 
na które suwerenność państwowa może być kwestionowana, i to w kategoriach moralnych. Suwerenność jest tu rozumiana jako odpowiedzialność za przestrzeganie praw człowieka, są one zatem autorytetem określającym działania władz państwa. Wobec tego, w zredefiniowanym pojęciu suwerenności nie jest przeciwstawiona prawom człowieka, ale czyni je warunkiem i gwarantem osiągania oraz utrzymywania suwerenności.

Państwa określające swoją suwerenność w zredefiniowanej wersji - w oparciu o przestrzeganie praw człowieka i dotrzymywanie warunków umowy społecznej - miałyby tę samą podstawę, która przysługuje koncepcji globalnego obywatelstwa. Globalne obywatelstwo jest bowiem ufundowane na międzynarodowym uznaniu praw człowieka ${ }^{18}$. Tak rozumiane obywatelstwo mogłoby praktycznie funkcjonować wśród obywateli różnych suwerennych państw. Interwencja humanitarna byłaby wówczas postrzegana nie jako bezprawne wtargnięcie na obcy teren, choćby z pobudek moralnych, ale jako wyraz przestrzegania globalnego obywatelstwa - obrony jednostek w sytuacji naruszania praw człowieka.

Badając relacje między ideą suwerenności państw i prawami człowieka, nie wolno zapominać, że suwerenność państw może być nie tylko przeszkodą w realizacji praw człowieka, ale czasem także warunkiem ich przestrzegania. Dzieje się tak najczęściej w okolicznościach globalnego kapitalizmu, który dotyka najbiedniejszych państw trzeciego świata. Słabe, mało autonomiczne państwa, ulegając niekontrolowanym siłom globalnym, nie są w stanie wystarczająco chronić praw swoich obywateli, a nawet przyczyniają się do ich łamania. Im mniej są niezależne, tym bardziej podatne na wyniszczające je globalne tendencje. Wówczas okazuje się, że to silne instytucje państwowe, wolne od zewnętrznych nacisków globalnych, mogą ustrzec obywateli przed wykorzystywaniem, i ostatecznie bronić ich praw (Benhabib, 2007). Należy zatem wyjść poza przyjęty dość powszechnie w analizach tematu aksjomat, że osłabienie suwerenności państw narodowych wiąże się ze wzmocnieniem przestrzegania praw człowieka na świecie. Obok wzmacniania instytucji wewnętrznych państwa należy równocześnie rozwijać instytucje międzynarodowe kontrolujące przestrzeganie praw człowieka. Interwencja humanitarna w tym kontekście nie może być postrzegana jako podważanie niepodległości państwa, ale współdziałanie z państwem na rzecz wzmocnienia jego niezależności wobec sił rynków globalnych. Ostatecznie

18 Zagadnienie globalnego obywatelstwa i jego stosunku zarówno do suwerenności, jak i praw człowieka ma własną obszerną literaturę (Dower, Williams, 2002; Benhabib, 2007; Fine, 2009). 
państwa trzeciego świata i instytucje międzynarodowe broniące praw człowieka mają ten sam cel - ochronę obywateli.

Uważam, że owa redefinicja roli praw człowieka może mieć głębokie konsekwencje dla - w zależności jak będziemy ujmować międzynarodową scenę polityczną - globalnego systemu politycznego, międzynarodowego systemu państw narodowych, czy nawet dla wizji globalnego obywatelstwa. Przede wszystkim chodzi o możliwość powiązania, a nie traktowania wyłącznie, tendencji do samorealizacji państw, to znaczy nastawienia na obronę interesów narodowych, do czego potrzebna jest suwerenność, z uznaniem przez te państwa uniwersalnego statusu obowiązywania praw człowieka. Państwa nie traktują wówczas praw człowieka jako przeszkody w dążeniu do autonomii. Prawa człowieka stanowią nie absolutną, ale jedną z wielu instytucji obiektywizujących potrzeby i dążenia obywateli. Przykładem może być tu sądownictwo Unii Europejskiej, równoległe do sądownictwa państw narodowych. Systemy prawne uzupełniają się, ale jedne dają również ochronę przed drugimi na korzyść obywateli. Demokratyczne państwa z zasady ustrojowej nie powinny mieć tendencji do unieszczęśliwiania i niesprawiedliwego traktowania swoich obywateli, zatem jeśli istnieje możliwość legalnej, pozapaństwowej weryfikacji działań państwa, tak by nie traciło ono jeszcze roszczenia do suwerenności, to dla wszystkich trzech stron - rządzących, obywateli i zewnętrznych aktorów - wydaje się dobrym rozwiązaniem. Prawa człowieka jako jeden $\mathrm{z}$ warunków suwerenności mogą nie tylko stanowić usprawiedliwienie dla podejmowania interwencji humanitarnych - co traktowane jest jako ostateczność. Pierwotnie, stanowić mogą źródło weryfikacji i ewentualnej korekty działań państwa, daleko wcześniej zanim potrzebna byłaby interwencja humanitarna. W istocie bowiem warunkowe definiowanie suwerenności w perspektywie nowej roli praw człowieka umożliwia także mniej inwazyjne interwencje ${ }^{19}$.

\section{BIBLIOGRAFIA:}

Ayoob, M. (2002). Humanitarian Intervention and State Sovereignty. The International Journal of Human Rights, vol. 6, $\mathrm{nr} 1$.

Baer, D. (2011). The Ultimate Sacrifice and the Ethics of Humanitarian Intervention. Review of International Studies, $n r 37$.

Beitz, Ch.R. (1994). Cosmopolitan Liberalism and the State System. W: C. Brown (red.), Political Restructuring in Europe. London: Routledge.

19 Artykuł powstał w oparciu o badania prowadzone przeze mnie w ramach grantu Narodowego Centrum Nauki, Sonata, nr 2011/01/D/HS5/01465. 
Bellamy, A.J. (2003). Humanitarian Responsibilities and Interventionist Claims in International Society. Review of International Studies, vol. 29.

Benhabib, S. (2007). Twilight of Sovereignty or the Emergence of Cosmopolitan Norms? Rethinking Citizenship in Volatile Times. Citizenship Studies, vol. 11, nr 1.

Butterfield, H., Wight, M. (1966). Diplomatic Investigations: Essays in the Theory of International Politics. London: Allen \& Unwin.

Czaputowicz, J. (2008). Teorie stosunków międzynarodowych. Krytyka i systematyzacja. Warszawa: PWN.

Devetak, R. (2007). Between Kant and Pufendorf: Humanitarian Intervention, Statist Anti-Cosmopolitanism and Critical International Theory. Review of International Studies, $n$ r 33.

Dower, N., Williams J. (red.). (2002). Global Citizenship. A Critical Reader. Edinburgh: Edinburgh University Press.

Dróżdż, D. (2014). Interwencje humanitarne a suwerenność państwa. Realizowanie utopii - usprawiedliwianie użycia sity zbrojnej poprzez prowadzenie interwencji humanitarnej. Łódź: Wydawnictwo Społecznej Akademii Nauk.

Evans, G. (2008). The Responsibility to Protect. Ending Mass Atrocity Crimes Once and for All. Washington DC: The Brookings Institution.

Fine, R. (2009). Cosmopolitanism and Human Rights: Radicalism in a Global Age. Metaphilosophy, vol. 40, $\mathrm{nr} 1$.

Forsythe, D.P. (2000). Human Rights in International Relations. Cambridge: Cambridge University Press.

Gomes, B. (2010). The Duty to Oppose Violence: Humanitarian Intervention as a Question for Political Philosophy. Review of International Studies, vol. 37, nr 3.

Góralczyk, W., Sawicki, S. (1995). Prawo międzynarodowe publiczne. Warszawa: Wolters Kluwer.

Held, D. (1995). Democracy and the Global Order. From the Modern State to Cosmopolitan Governance. Stanford: Stanford University Press.

Hobbes, T. (2009). Lewiatan, czyli materia, forma i władza państwa kościelnego świeckiego. Warszawa: Aletheia.

Kant, I. (2007). Metafizyka moralności. Warszawa: PWN.

Makinda, M.S. (2002). The Global Covenant as an Evolving Institution. The International Journal of Human Rights, vol. 6, nr 1.

Mężykowska, A. (2008). Interwencja humanitarna w świetle prawa międzynarodowego. Warszawa: Wydawnictwo WSHiP im. R. Łazarskiego.

Morgenthau, H. (1978). Politics Among Nations. Struggle for Power and Peace. New York: Knopf.

Moses, J. (2006). Challenging Just War and Democratic Peace: A Critical Perspective on Kant and Humanitarian intervention. W: C. Enemark (red.), Ethics of War in a Time of Terror, Canberra Papers on Strategy and Defence, nr 163. Canberra: Strategic and Defence Studies Centre. 
Owens, P. (2005). Hannah Arendt, Violence, and the Inescapable Fact of Humanity.W: A. Lang Jr., I.J. Williams (red.), Hannah Arendt and International Relations: Readings Across the Lines. London: Palgrave.

Reisman, W.M. (1990). Sovereignty and Human Rights in Contemporary International Law. The American Journal of International Law, vol. 84.

Rezolucja Zgromadzenia Ogólnego ONZ. (1970). Deklaracja zasad prawa międzynarodowego dotyczących przyjaznych stosunków i współdziałania państw zgodnie z Kartą Narodów Zjednoczonych.

Roberts, A. (2000). The So-Called 'Right' of Humanitarian Intervention. Yearbook of International Law, nr 3.

Rougier, A. (1910). La theorie de l'intervention d'humanite. Revue Genevoise du Droit International Public, nr 17, 26.

Schmitz, H.P., Sikkink, K. (2002). International Relations Theory and Human Rights. W: W. Carlsnaes, T. Risse, B. Simmons (red.), Handbook of International Relations. London: Sage.

Spalding, L.J. (2013). A Critical Investigation of the IR Theories that Underpin the Debate on Humanitarian Intervention. International Public Policy Review, vol. 7 , nr 2.

Teson, F. (2003). The Liberal Case for Humanitarian Intervention. W: J.L. Holzgrefe, R.O. Keohane (red.), Humanitarian Intervention: Ethical, Legal and Political Dilemmas. Cambridge: Cambridge University Press.

Thomas, H. (2004). Cosmopolitan Sovereignty. Paper presented to the Australian Political Studies Association Conference, Universitz of Adelaide, 29 September - 1 October.

Turkot, M. (2016). Między ideą suwerenności państw a globalnym wymiarem praw człowieka - kosmopolityczny projekt ładu międzynarodowego według Seyli Benhabib. W: Studia Polityczne, vol. 3. Warszawa: Instytut Studiów Politycznych Polskiej Akademii Nauk.

Vincent, R.J. (1974). Nonintervention and International Order. Princeton: Princeton University Press.

Vincent, R.J. (1986). Human Rights and International Relations. Cambridge: Cambridge University Press. 